\title{
Nedkjøling under hjerte-lunge-redning?
}

\author{
Terapeutisk nedkjøling under pågående hjerte-lunge-redning har ikke \\ innvirkning på overlevelse, inflammasjonsmarkører eller hjernefunk- \\ sjon, viser en fransk studie.
}

Terapeutisk nedkjøling ved hjertestans er anbefalt så raskt som mulig etter at sirkulasjonen er kommet $\mathrm{i}$ gang. I en fransk studie som nylig ble publisert i Intensive Care Medicine, har man undersøkt om nedkjøling allerede under pågående hjerte-lunge-redning,

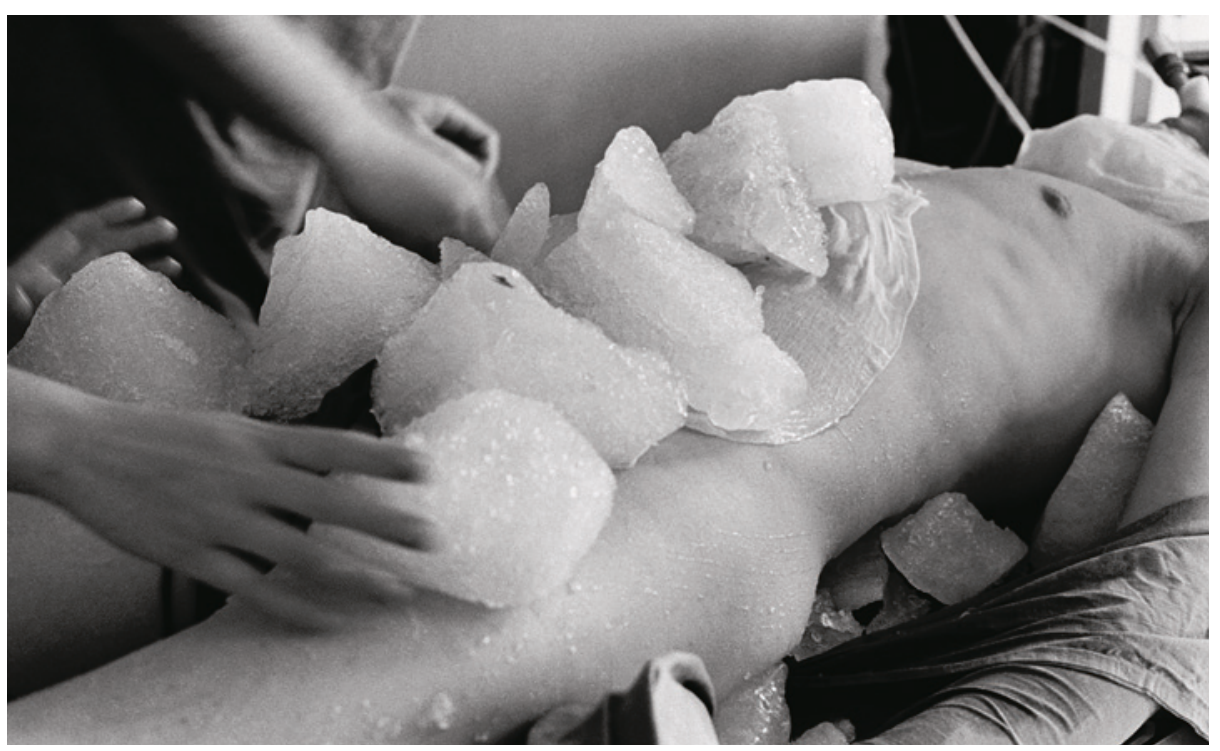

Illustrasjonsfoto: Science Photo Library dvs. før sirkulasjonen har kommet i gang, kan være gunstig (1).

Pasienter med prehospital hjertestans ble randomisert til infusjon av kaldt saltvann og ekstern kjøling under pågående hjerte-lungeredning $(\mathrm{n}=123)$ eller nedkjøling etter inn-

leggelse i sykehus $(n=122)$. Nedkjøling under pågående hjerte-lunge-redning forkortet tiden til ønsket temperatur $\left(\leq 34{ }^{\circ} \mathrm{C}\right)$ med 75 minutter. Andelen pasienter som nådde sykehuset i live, var lik i begge gruppene. Det var ingen forskjell i nivå av nevronspesifikk enolase eller i inflammasjonsmarkører mellom gruppene. Etter én måned var det ingen forskjell i overlevelse eller hjernefunksjon.

- Intervensjonsgruppen nådde måltemperatur over én time før kontrollgruppen uten gevinst på overlevelse eller hjernefunksjon, men utvalgsstørrelsen var primært beregnet for å finne forskjeller i nevronspesifikk enolasenivå og ikke i overlevelse eller hjernefunksjon, sier Trond Nordseth, som er overlege og ph.d. ved Anestesiavdelingen, St. Olavs hospital og leder av Norsk Resuscitasjonsråd.

- Det var en tendens til bedre hjernefunksjon $\mathrm{i}$ intervensjonsgruppen, og mer omfattende tester kunne potensielt vist om nedkjøling under pågående hjerte-lunge-redning beskytter hjernen bedre enn ved nedkjøling etter innleggelse. Nytten av terapeutisk hypotermi på langtids kognitiv funksjon er fortsatt uavklart, sier Nordseth.

\section{Liv-Ellen Vangsnes}

Tidsskriftet

\section{Litteratur}

1. Debaty G, Maignan M, Savary D et al. Impact of intra-arrest therapeutic hypothermia in outcomes of prehospital cardiac arrest: a randomized controlled trial. Intensive Care Med 2014; 40: 1832-42.

\section{Måling av natriuretiske peptider ved hjertesvikt}

\section{Natriuretiske hjertepeptider er gode markører for å utelukke akutt hjertesvikt, men kan ikke alene bekrefte diagnosen.}

Måling av natriuretiske hjertepeptider kan gi et viktig bidrag til diagnose og behandling av hjertesvikt. I en britisk metaanalyse er diagnostisk nøyaktighet av serumnivåer av natriuretiske peptider undersøkt hos pasienter med mistenkt akutt hjertesvikt, ut fra terskelverdier anbefalt $\mathrm{i}$ europeiske retningslinjer (1).

Over 15000 testresultater fra 37 studiekohorter ble inkludert i analysen. Ved terskelverdiene $100 \mathrm{ng} / \mathrm{l}$ for B-type natriuretisk peptid (BNP) og $300 \mathrm{ng} / \mathrm{l}$ for N-terminale fragmenter av proBNP (Nt-proBNP) fant man en sensitivitet på henholdsvis $0,95 \mathrm{og}$ 0,99 og negativ prediktiv verdi på henholdsvis 0,94 og 0,98 for diagnosen akutt hjertesvikt. Ved høyere terskelverdier avtok sensitiviteten progressivt, og spesifisiteten forble variabel i området. Det var ingen statistisk signifikant forskjell i diagnostisk nøyaktighet mellom BNP-nivåer og Nt-proBNPnivåer.

- Resultatene bekrefter at de anbefalte grenseverdiene for BNP og Nt-proBNP er godt egnet til å utelukke akutt hjertesvikt og kan brukes uavhengig av pasientens alder og kjønn, sier lege og ph.d. Sara R. Ulimoen ved Medisinsk avdeling, Bærum sykehus. Måling av natriuretiske peptider i akuttmottak eller legevakt gir rask og pålitelig diagnostisk informasjon, noe som spesielt er nyttig der ekkokardiografi ikke er døgnkontinuerlig tilgjengelig. Ved BNP $<100$ ng/l eller Nt-proBNP $<300$ ng/l er det svært lite sannsynlig at pasientens symptomer skyldes akutt hjertesvikt. Men spesifisiteten er kun moderat, slik at ved forhøyede nivåer av natriuretiske peptider må diagnosen fortsatt bekreftes ved for eksempel ekkokardiografi. Hjertesvikt med bevart ejeksjonsfraksjon er også vanligvis forbundet med lavere utslipp av natriuretiske peptider enn hjertesvikt med redusert ejeksjonsfraksjon, sier Ulimoen.

Trine B. Haugen

Tidsskriftet

Litteratur

1. Roberts E, Ludman AJ, Dworzynski K et al. The diagnostic accuracy of the natriuretic peptides in heart failure: systematic review and diagnostic meta-analysis in the acute care setting. BMJ 2015: 350: h910. 